\title{
Content validity of an educational workshop based on the Dietary Guidelines for the Brazilian Population
}

\author{
Validade de conteúdo de uma oficina \\ educativa baseada no Guia Alimentar
}

para a População Brasileira

\author{
Patricia Constante JAIME ${ }^{1}$ (D) 0000-0003-2291-8536 \\ Cláudia Raulino TRAMONTT² (D) 0000-0001-7264-9317 \\ Tarsis de Mattos MAIA² (D) 0000-0001-7265-1679 \\ Kamila Tiemann GABE ${ }^{2}$ iD 0000-0001-5138-9552 \\ Lígia Cardoso dos REIS² (D) 0000-0001-9708-2230
}

A B S T R A C T

\section{Objective}

To describe the development and validation of a workshop protocol for the implementation of the Dietary Guidelines for the Brazilian Population in primary healthcare units.

\section{Methods}

This descriptive study was developed in the state of São Paulo, Brazil, and it involved 20-25 professionals in the experimentation phase and 12 experts in the content validity phase. The workshop protocol was developed according to three theoretical references: Dietary Guidelines, Interprofessional Collaborative Practice and Critical Reflexive Methodology. The protocol consisted of four 4-hour modules, 16 activities in 16 hours. The activities matrix was composed of three axes: (a) organizational strategies, (b) dietary guideline comprehension and

\footnotetext{
1 Universidade de São Paulo, Faculdade de Saúde Pública, Núcleo de Pesquisas Epidemiológicas em Nutrição e Saúde. Av. Dr. Arnaldo, 715, Cerqueira César, 01246-000, São Paulo, SP, Brasil. Correspondência para/Correspondence to: PC JAIME. E-mail: <constant@usp.br>

2 Universidade de São Paulo, Faculdade de Saúde Pública, Programa de Pós-Graduação em Nutrição em Saúde Pública. São Paulo, SP, Brasil.

Support: The International Development Research Centre - IDRC (Processo n²3447), e Conselho Nacional de Desenvolvimento Científico e Tecnológico - CNPq (Processo n408115/2017-3)
}

Como citar este artigo/How to cite this article

Jaime PC, Tramontt CR, Maia TM, Gabe KT, Reis LC. Content validity of an educational workshop based on the Dietary Guidelines for the Brazilian Population. Rev Nutr. 2018;31(6):593-602. http://dx.doi.org/10.1590/1678-98652018000600008 
(c) dietary guideline implementation. For the validity analysis, the expert panel assessed clarity, relevance and theoretical representativeness. Content validity index was calculated, and adequate activities scored $>0.80$. The proportion of experts who recognized the presence of the theoretical framework in the activities was calculated.

\section{Results}

All 16 proposed activities obtained a score greater than the established cut-off point, both for clarity and relevance. For theoretical representativeness analysis, the dietary guidelines reached higher scores on the (b) and (c) axes of the protocol and was less recognized on the (a) axis, whose highest score was for the Critical Reflexive Methodology. Interprofessional Collaborative Practice presented a higher score on the (c) axis and a lower one on the (b) axis.

\section{Conclusion}

The protocol was considered appropriate for its purpose and with potential application in the different scenarios of primary health care in Brazil.

Keywords: Food and Nutrition Education. Food Guides. Health personnel. Primary Health Care.

\section{RE S U M O}

\section{Objetivo}

Descrever o desenvolvimento e validação de um protocolo de oficina de educação permanente para implementação do Guia Alimentar para a População Brasileira no âmbito da atenção primária à saúde.

\section{Métodos}

Este estudo descritivo foi desenvolvido no estado de São Paulo. Participaram do estudo 20-25 profissionais de saúde na fase de experimentação e 12 doze especialistas na fase de validação de conteúdo. O protocolo da oficina foi desenvolvido de acordo com três referenciais teóricos: o Guia Alimentar, a Prática Colaborativa Interprofissional e a Metodologia Crítico Reflexiva. O protocolo da oficina foi definido em 4 módulos com 16 atividades, em 16 horas. A matriz de atividades compreendeu três eixos: (a) estratégias organizacionais, (b) compreensão do Guia Alimentar e (c) implementação do Guia Alimentar. Para validação de conteúdo o painel de especialistas avaliou a clareza, relevância e representatividade teórica do protocolo. Índice de validade de conteúdo foi calculado e atividades adequadas pontuaram $>0,80$. A proporção de especialistas que reconheceu a presença do referencial teórico nas atividades foi calculada.

\section{Resultados}

Todas as 16 atividades propostas obtiveram escores maiores do que o ponto de corte estabelecido, tanto para clareza como para relevância. Na análise da representatividade teórica, o Guia Alimentar alcançou escores mais altos nos eixos (b) e (c), e foi menos reconhecido no eixo (a), cuja maior pontuação ocorreu para a Metodologia Crítico Reflexiva. A Prática Colaborativa Interprofissional apresentou maior pontuação no eixo (c) e menor no eixo (b).

\section{Conclusão}

O protocolo foi considerado adequado à sua finalidade e com potencial de aplicação nos diversos cenários da atenção primária à saúde no Brasil.

Palavras-chave: Educação Alimentar e Nutricional. Guias Alimentares. Pessoal de saúde. Atenção Primária em Saúde.

\section{NTROD U CTION}

Significant changes in the dynamics and lifestyle in Brazil and other SouthAmerican countries have deeply impacted the epidemiological and nutritional profiles of the population, resulting in the predominance of
Non-Communicable Diseases (NCD) as the main cause of morbimortality $[1,2]$.

This current situation requires healthcare networks, which are coordinated by Primary Health Care services (PHC), to focus attention on NCD to promote continuous education of health professionals and encourage a multidisciplinary 
approach towards work [3]. As unhealthy eating patterns are important changeable risk factors for $N C D$, advances in the qualification of healthcare professionals and health management have become urgent $[4,5]$.

Taking into account the multidisciplinary team work approach, the sharing of knowledge and responsibilities between the nutritionist, traditionally responsible for diet and nutrition care, and other PHC professionals is essential to develop and strengthen a common field of information and practices to promote appropriate and healthy eating [6]. Dietary guidelines, defined as an instrument used by countries to establish and communicate the recommendations for their populations' diets, play a crucial role in equipping professionals with necessary technical knowledge for this purpose $[7,8]$.

The successful implementation of these tools depends on the training of potential facilitators [8], including multi-professional PHC teams. The training of these professionals requires a methodology aligned with the Brazilian permanent health education policy [9]. This policy considers the work environment to be a favourable place to foster knowledge acquisition. Through the problematization of daily issues and transformation of practices and realities experienced, this policy engages with international discussions on interprofessional collaborative practice $[10,11]$.

The aim of the present study was to develop and validate an educational workshop protocol for primary healthcare professionals to promote the implementation of the Guia Alimentar para a População Brasileira (Dietary Guidelines for the Brazilian Population).

\section{METHODS}

This is a descriptive study on the development and validation of a workshop protocol with the following objectives: to present the principles and recommendations of the Dietary Guidelines, discuss the use of this educational tool for the promotion of healthy eating in PHC and contribute to include it in the work process of PHC teams. The protocol design was based on the following theoretical framework:

1) Dietary Guidelines for the Brazilian Population (Dietary Guidelines)

This document is the official Brazilian reference for the promotion of healthy eating. It was developed to guide policies and health actions related to food and nutrition safety [12]. The Dietary Guidelines innovates the way diet and nutrition are considered by recognising the limitations found in the epidemiological and biomedical approaches that reduce food practices to nutrient intake, and by incorporating cultural, socioeconomic and environmental aspects of eating. In parallel, the guide contributes to overcoming obstacles towards healthy eating on both individual and collective levels through the adoption of a holistic view of dietary habits $[13,14]$.

2) Interprofessional Collaborative Practice (ICP)

In association with the procedures of the PHC teamwork, ICP is characterized as healthcare professionals from different clinical and non-clinical areas, who provide services based on a comprehensive care approach that involves patients, families, carers and communities [10]. The ICP was devised as a result of the challenges and complexities faced by healthcare professionals due to changes in the epidemiological profile, population aging and prolonged evolution of the NCD in a way that these professionals may together propose effective interventions [15].

3) Critical Reflexive Methodology (CRM)

The CRM is based on Freire's pedagogical theory [16]. The incorporation of Freire's critical pedagogy in the design of the workshop was important to consider the experiences of the PHC teams related to the promotion of healthy eating. 
Therefore, the need of educational techniques was identified to encourage participation, based on the reflection-action process, and to rescue and value the knowledge obtained from reality along with the one obtained from the training process, thus consolidating the "learning by practice" concept [17]. This perspective is in line with international recommendations for rethinking pedagogical approaches used in the training of health professionals in terms of empowerment [18]. Freire's concept of problemposing education [16] underlies the reflective practice that implies a constant act of unveiling reality, based on dialogue and a hierarchy-free teacher-student relationship.

We selected the workshop as the most adequate strategy because it enables a collective knowledge building from real life situations and a deeper reflection and exchange of experiences among participants, confronting practice with theory through a responsible engagement $[19,20]$. Its dynamics is based on Freire's dialogic concept i.e. equal dialogue in the relationship between teacher and student [21].

The construct and validity processes of the workshop protocol took place in three stages, as described below.

\section{Workshop protocol development}

The workshop protocol was developed by researchers from the Centre for Epidemiological Research in Nutrition and Health at the Universidade de São Paulo (USP, University of São Paulo), Brazil, by experts in the Dietary Guidelines and healthcare professionals with experience in PHC education.

A matrix of activities was developed and organized in three axes: (a) organizational strategies, (b) Dietary guideline comprehension and (c) Dietary guideline implementation. Axis (a) refers to activities that present the workshop and the team, welcome participants and establish ground rules; closure and evaluation. Axis (b) addresses the content of each chapter of the document, emphasizing its recommendations. Axis (c) aims to contextualize the recommendations in professional practice and assist in the application of the Dietary Guidelines as a tool for the promotion of healthy eating. Titles, objectives, duration, necessary material, explanation on how to conduct the activity, expected results and theoretical references were provided for each activity.

The protocol workshop consisted of four 4-hour modules, totalizing 16 activities and 16 hours. This format enables the implementation of the workshop according to the needs and routine of the teamwork.

Based on the principles of problemposing pedagogy, each module initiated with an introductory activity to provide the participants with a clear understanding of the proposals to be worked on. Given that time intervals set for implementing the modules may vary, content revision activities were included to review previous modules and stimulate connections among subjects.

The activities were designed to allow the participants to review previous knowledge, analyze their work context and reality and, from there, collectively construct concepts, reflect on their practice in a multi-professional team and propose strategies for intervention at work using the Dietary Guidelines as the main technical reference for the activities. These activities were designed to allow a practical and contextualized application of this educational tool.

\section{Workshop protocol experimentation}

A pre-test of the workshop was carried out with five multidisciplinary PHC teams from a medium-sized town in the state of São Paulo. The teams were divided into groups of 20 to 25 participants. The aim was to test the adequacy of the activities proposed and clarity of the descriptive workshop protocol manual as well as 
identify any necessary adjustments. The revised workshop protocol was then presented to four PHC multidisciplinary teams, of 20-25 individuals each, in a similar city.

Two trained facilitators and a trained supporter were needed to conduct the workshop activities. The facilitator was responsible for leading the activities, acting not only as a mediator, but encouraging reflections and discussions in the group, guiding collective construction of knowledge, and encouraging participant self-awareness of attitudes and opinions in an ethical and democratic way [21]. In the workshop context, the supporter worked together with the facilitator in the background, assisting the organization of materials before, during and after the workshop.

\section{Workshop protocol validation}

The workshop protocol was submitted to content validation to determine the representativeness of the theoretical references used for its development [22]. A panel of experts identified the presence of the theoretical references used to prepare each activity. In this process, clarity, relevance and the theoretical framework were assessed [22-24].

The experts were selected by intentionality [22], adopting the following inclusion criteria: experience in the areas of permanent education in health and nutrition education (according to the critical reflexive methodology), ICP and knowledge on the Dietary Guidelines. The experts received a printed copy in advance of the document, a summary of the theoretical framework used in the workshop, the detailed activities and methodology instructions of the panel.

The panel of experts were present at a 3-hour session and the following questions were assessed: (1) "Was the description of the activity clear and comprehensible enough to be reproduced in PHC contexts nationwide?"; (2)
"Was the activity sufficiently pertinent to the aims of the workshop?"; and (3) "Which of the theoretical references could be identified in the activity?".

The assessment of clarity and relevance occurred on a scale of 1 to 4 ( 1 = activity irrelevant and unclear for the workshop protocol, 2= significant alterations are necessary to make the activity relevant/clear; $3=$ small alterations are necessary to make the activity relevant/clear, $4=$ the activity is relevant/clear). When the activities were considered unclear and/or irrelevant (score equal to or below 3), the experts were asked to justify their answers in a specific section available for this purpose.

The experts analyzed the presence of each theoretical reference in the activities (theoretical representativeness assessment) using a questionnaire that also provided space for suggestions and general comments about the protocol.

For the validity analysis, the Content Validity Index (CVI), which measures the proportion of experts who expressed agreement with respect to the protocol activities, was used. The CVI was calculated by the proportion of scores 3 and 4 for each activity divided by the total scores received (total of experts). The activities that scored $\mathrm{CVI}>0.80$ were considered adequate [22].

For the theoretical representativeness analysis, the proportion of experts who recognized the presence of the theoretical framework in the activities was calculated. The mean of these proportions was calculated for each theoretical reference to obtain an index per axis. A score (0 a 100) was generated for each theoretical reference.

This study is part of a research project approved by the Research Ethics Committee of the School for Public Health, University of São Paulo, under protocol No 2.042.902. All health professionals who participated in the workshops and the panel experts signed an informed consent form 
Twelve experts, whose characteristics are described in Table 1, participated in the panel of content validity.

The experts assessed each activity included in the workshop protocol. All 16 proposed activities obtained a score greater than the established cut-off point, both for clarity and relevance, and, therefore, remained in the workshop protocol. Of the 16 activities, 13 received a maximum score $(C V I=1.0)$ for relevance and 7 for clarity (Table 2). Experts' comments were analyzed and alterations were made when deemed pertinent, even those with a CVI greater than 0.80 . The changes included opening and ending activities of modules and text revision to facilitate understanding.

As part of the theoretical representativeness analysis, the proportion of experts who recognized the presence of each theoretical framework was calculated (Table 2). The theoretical reference of the Dietary Guidelines was widely recognized on the (b) and (c) axes, with scores above 90, and less recognized on axis (a), where the score was close to 30. On axis (a), CRM was the most recognized reference with a score of approximately 73 . This reference obtained a similar score on the other axes. The highest score of the ICP reference was on axis (c) (75) and the lowest on axis (b) (40).
The aim of this study was to present the development and content validation processes of a health education protocol, based on the Dietary Guidelines for the Brazilian Population, for PHC professionals. This objective met the current Política Nacional de Alimentação e Nutrição (PNAN, Brazilian National Food and Nutrition Policy) [25], according to which the development of technical mechanisms and organizational strategies for training and permanent education of health professionals is considered essential to promote healthy eating.

The development of the methods and materials to implement dietary guidelines was also recommended by the Food and Agriculture Organization of the United Nations [7]. More recently, the training of facilitators was considered a key element for the implementation of dietary guidelines [8]. In a survey on the development and implementation of dietary guidelines in South-American and Caribbean countries, most countries (16 out of 24 countries) used training as one of the ways to disseminate their guidelines and even relied on national policies devised for this objective [8]. This highlights the adequacy and relevance of the workshop protocol prepared in this study as it is in agreement with international recommendations.

Table 1. Characterization of the participants of the experts' panel (N=12). São Paulo (SP), Brazil, 2017.

\begin{tabular}{lc}
\hline Characteristic & Absolute frequency \\
\hline Profession & 11 \\
Nutritionist & 1 \\
Physiotherapist & 1 \\
Academic qualifications & 2 \\
Graduate - Nutrition & 9 \\
Masters - Nutrition/Public Health & \\
PhD - Nutrition/Public Health & 4 \\
Expertise on panel's theoretical reference & 4 \\
Dietary Guidelines for the Brazilian Population & 4 \\
Interprofessional Collaborative Practice & \\
Critical Reflexive Methodology & \\
\hline
\end{tabular}


Table 2. Content validity indices, proportion of experts who attributed theoretical references according to each activity and their respective averages per axis. São Paulo (SP), Brazil, 2017.

\begin{tabular}{|c|c|c|c|c|c|c|}
\hline \multirow{2}{*}{ Activities according to axes } & \multicolumn{3}{|c|}{$\begin{array}{c}\text { Content Validity Index (CVI) } \\
\left(n^{\circ} \text { answers } 3 \text { and 4/answers total) }\right.\end{array}$} & \multicolumn{3}{|c|}{$\begin{array}{l}\text { Theoretical Reference } \\
\text { recognised by experts (\%) }\end{array}$} \\
\hline & $\begin{array}{c}\text { Clarity } \\
\text { (min-max) }\end{array}$ & $\begin{array}{l}\text { Relevance } \\
\text { (min-max) }\end{array}$ & $\begin{array}{l}\text { CVI } \\
\text { Mean }\end{array}$ & DG & $\mathrm{ICP}$ & CRM \\
\hline \multicolumn{7}{|l|}{ Axis A. Organisational strategies } \\
\hline Programme and objectives of the workshop & $0.92(2-4)$ & $1.00(4-4)$ & 0.96 & 8.33 & 33.33 & 83.33 \\
\hline Ground rules & $1.00(3-4)$ & $1.00(3-4)$ & 1.00 & 0.00 & 66.67 & 75.00 \\
\hline Group welcome & $1.00(3-4)$ & $1.00(3-4)$ & 1.00 & 41.67 & 33.33 & 83.33 \\
\hline Closure and evaluation & $0.83(2-4)$ & $1.00(3-4)$ & 0.92 & 66.67 & 83.33 & 50.00 \\
\hline Total (average) & 0.94 & 1.00 & 0.97 & 29.17 & 54.17 & 72.92 \\
\hline \multicolumn{7}{|l|}{ Axis B. Understanding the Dietary Guidelines } \\
\hline What is your understanding of healthy eating? & $1.00(3-4)$ & $1.00(3-4)$ & 1.00 & 100.00 & 41.67 & 83.33 \\
\hline Mapping of epidemiological profiles of the territory & $0.83(3-4)$ & $1.00(3-4)$ & 0.92 & 41.67 & 66.67 & 83.33 \\
\hline Classifying food according to processing level & $0.83(2-4)$ & $0.92(2-4)$ & 0.88 & 100.00 & 16.67 & 41.67 \\
\hline Choosing foods & $0.92(2-4)$ & $0.92(2-4)$ & 0.92 & 100.00 & 16.67 & 41.67 \\
\hline From food to meals & $0.83(1-4)$ & $1.00(3-4)$ & 0.92 & 100.00 & 50.00 & 83.33 \\
\hline Reflecting on the act of eating and commensality & $1.00(3-4)$ & $1.00(3-4)$ & 1.00 & 100.00 & 33.33 & 83.33 \\
\hline Appropriating the act of eating and commensality & $1.00(3-4)$ & $1.00(3-4)$ & 1.00 & 100.00 & 25.00 & 50.00 \\
\hline $\begin{array}{l}\text { Understanding and overcoming healthy eating } \\
\text { obstacles }\end{array}$ & $1.00(3-4)$ & $1.00(3-4)$ & 1.00 & 100.00 & 83.33 & 100.00 \\
\hline 10 steps towards adequate and healthy eating & $1.00(3-4)$ & $1.00(3-4)$ & 1.00 & 100.00 & 25.00 & 41.67 \\
\hline Total (average) & 0.92 & 0.96 & 0.96 & 93.52 & 39.81 & 67.59 \\
\hline \multicolumn{7}{|l|}{ Axis C. Implementing the Dietary Guidelines } \\
\hline $\begin{array}{l}\text { Reflecting on the promotion of healthy eating as } \\
\text { team practice }\end{array}$ & $0.92(2-4)$ & $1.00(3-4)$ & 0.96 & 83.33 & 91.67 & 91.67 \\
\hline Equipping the professional & $0.92(2-4)$ & $0.92(2-4)$ & 0.92 & 91.67 & 58.33 & 41.67 \\
\hline Using the Dietary Guidelines in professional practice & $0.92(2-4)$ & $1.00(3-4)$ & 0.96 & 100.00 & 75.00 & 66.67 \\
\hline Total (average) & 0.92 & 0.96 & 0.94 & 91.67 & 75.00 & 66.67 \\
\hline
\end{tabular}

Note: DG: Dietary Guidelines for the Brazilian Population; ICP: Interprofessional Collaborative Practice; CRM: Critical Reflexive Methodology.

The experimentation phase was important to ensure the viability of the workshop protocol by testing its operational details. The pilot workshop demonstrated adequacy both in terms of the workloads and time scheduling of facilitators. The division into modules allows workshop implementation in different PHC settings, since it helps to overcome logistical difficulties associated with different work routines.

Content validation was performed to verify the adequacy of the workshop for the proposed objectives and the pre-defined theoretical references. The panel of experts used at this stage is commonly recognized in questionnaire validation $[22,26]$. Its use, however, can also be observed in other contexts such as in content validation of health educational materials and clinical protocols $[27,28]$. Considering that the aims of this study were achieved, the methodology was found to be appropriate for this context by the panel of experts.

All activities were considered relevant and clear by the experts (according to the $\mathrm{CVI}$ ) and were, therefore, maintained in the workshop protocol. The open questions enabled the identification of suggestions for changes in the 
description and/or framework of some activities, supporting additional qualitative assessments.

Regarding the representativeness analysis according to the axes, all theoretical references were recognized, at a greater or lesser frequency, depending on the characteristics of the activities.

In the activities from axis (a), organisational strategies, the most perceived theoretical reference by the experts was CRM. This was expected as participants are involved in the decision-making process about their own learning in this set of activities. The importance of participants' autonomy and freedom is one of the expectations of this theoretical framework $[16,21]$.

Still considering this axis, the final activity with a circular dance was highlighted as consistent with ICP. In fact, circular dancing, as an option in healthcare, allows professionals to reinforce the idea of a practice in which all participants involved share caring acts [6].

A further interesting observation is that the Dietary Guidelines recognized in this axis of activities provided reception and integration among the participants whilst at the same time allowing for the introduction and familiarization of the topic itself.

On axis (b), the Dietary Guidelines were recognised in all activities, with a lower identification in cartography (41.67\%), an exploratory activity on epidemiological characteristics of the territory that does not address specific recommendations of the document. Although this activity was not directly associated by the experts, it comprises the principle that "dietary recommendations need to be tuned to their times" [12]. It translates the perception of the setting for epidemiological, nutritional and dietary transformations of the populations. In addition, the practice of nutrition education in public policies considers local diagnosis as an essential part of their planning process [29]. For this reason, inclusion of activities that stimulate a critical-reflective analysis of local reality is important for its implementation, whether as educational actions developed for the population or as the multiplication and dissemination of knowledge to other professionals in health and other sectors.

Continuing axis (b), the CRM and the ICP were recognized in all activities. It confirmed the initial intention of workshop that was to guide PHC professional practices towards the effective application of the Dietary Guidelines, supported by Freire's pedagogy [16], and promote the sharing of knowledge and practices amongst them.

The Dietary Guidelines were related to all the activities on the (c) axis, as well as CRM and ICP. This shows a satisfactory identification of all the theoretical framework on this axis, whose objective was to explore the applicability of the guide in professional practice through dialogue and collaboration.

Although the lack of comparative studies may represent a possible weakness of this study, the adaptation of the content validity methodology with a panel of experts met the objectives of the research and proved to be a pioneering study using this type of analysis. The composition of the panel, with the presence of experts from different regions of the country, reinforced the use of the workshop protocol in a broader way, in different contexts and, at the same time, the protocol may be adapted accordingly as needed.

\section{CONCLUSION}

The workshop protocol proposed in this study is innovative and has the potential to be applied in various PHC settings all over the country. It can inspire other similar studies, thus improving the quality of the support materials designed for healthcare professional training. We expected that this proposal may contribute to the improvement in the quality of educational actions involving the promotion of healthy eating in PHC. 


\section{CONTRIBUTORS}

PC JAIME designed the study and contributed to data collection, interpretation of the results, drafting of the manuscript, and submission process. CR TRAMONTT, TM MAIA, KT GABE, and LC REIS contributed to data collection, interpretation of the results, and drafting of the manuscript. All authors revised, and approved the final version of the manuscript.

\section{A C KNOWLEDGMENTS}

The authors thank all the health professionals and experts who voluntarily participated in this study.

\section{REFERE NCE S}

1. Pan American Health Organization. Ultra-processed food and drink products in Latin America: Trends, impact on obesity, policy implications. Washington (DC): PAHO; 2015 [cited 2018 Aug 16]. Available from: http://iris.paho.org/xmlui/bitstream/handle/ 123456789/7699/9789275118641_eng.pdf

2. Brasil. Ministério da Saúde. Vigitel Brasil 2017: Vigilância de fatores de risco e proteção para doenças crônicas por inquérito telefônico. Brasília: Ministério da Saúde; 2018 [acesso 2018 ago 16]. Disponível em: http://bvsms.saude.gov.br/ bvs/publicacoes/vigitel_brasil_2017_vigilancia_ fatores_riscos.pdf

3. Mendes EV. As redes de atenção à saúde. 2a ed. Brasília: Organização Pan-Americana da Saúde; 2011 [acesso 2018 ago 16]. Disponível em: https:// www. paho.org/bra/index.php?option=com_ docman\&view=download\&category_slug= servicos-saude-095\&alias $=1402$-as-redesatencao-a-saude-2a-edicao-2\&ltemid=965

4. Pan American Health Organization. Integrated Health Service Delivery Networks: Concepts, Policy Options and a Road Map for Implementation in the Americas. Washington (DC): PAHO; 2011 [cited 2018 Aug 16]. Available from: https://www. paho.org/hq/dmdocuments/2011/PHC_IHSD2011Serie4.pdf

5. World Health Organization. Global action plan for the prevention and control of noncommunicable diseases 2013-2020. Geneva: WHO; 2013 [cited 2018 Aug 16]. Available from: http://apps.who. int/iris/bitstream/handle/10665/94384/9789241 506236_eng
6. Brasil. Ministério da Saúde. Contribuições dos núcleos de apoio à saúde da família para a atenção nutricional. Brasília: Ministério da Saúde; 2017 [acesso 2018 ago 16]. Disponível em: http://bvsms. saude.gov.br/bvs/publicacoes/contribuicoes_ saude_familia_atencao_nutricional.pdf

7. World Health Organization. Preparation and use of food-based dietary guidelines. Geneva: WHO; 1998. Report of a Joint FAOMHO Consultation.

8. Organización de las Naciones Unidas para la Alimentación y la Agricultura. El estado de las guías alimentarias baseadas en alimentos en América Latina y el Caribe: 21 años después de la Conferencia Internacional sobre Nutrición. Roma: FAO; 2014 [acceso 2018 ago 16]. Disponible en: http://www.audyn.org.uy/sitio/repo/arch/i3677s. pdf

9. Brasil. Ministério da Saúde. Política nacional de educação permanente em saúde. Brasília: Ministério da Saúde; 2009 [acesso 2018 dez 20]. Disponível em: http://bvsms.saude.gov.br/bvs/ publicacoes/pacto_saude_volume9.pdf

10. World Health Organization. Framework for action on interprofessional education and collaborative practice. Geneva: WHO; 2010.

11. World Health Organization. Transforming and scaling up health professionals' education and training: World Health Organization guidelines 2013. Geneva: WHO; 2013 [cited 2018 Aug 16]. Available from: http://apps.who.int/iris/bitstream/ handle/10665/93635/9789241506502_eng. pdf? sequence $=1$

12. Brasil. Ministry of Health. Dietary Guidelines for the Brazilian Population. Brasilia: Ministry of Health of Brazil; 2014 [cited 2018 Aug 16]. Available from: http://bvsms.saude.gov.br/bvs/publicacoes/ dietary_guidelines_brazilian_population.pdf

13. Oliveira MS, Amparo-Silva L. Food-based dietary guidelines: A comparative analysis between the Dietary Guidelines for the Brazilian Population 2006 and 2014. Public Health Nutr. 2017;21(1):210-7.

14. Monteiro C, Cannon G, Moubarac J, Martins AP, Martins CA, Garzillo J, et al. Dietary guidelines to nourish humanity and the planet in the twentyfirst century: A blueprint from Brazil. Public Health Nutr. 2015;18(13):2311-22.

15. Southerland JH, Webster-Cyriaque J, Bednarsh $\mathrm{H}$, Mouton CP. Interprofessional collaborative practice models in chronic disease management. Dent Clin North Am. 2016;60(4):789-809.

16. Freire P. Pedagogy of the oppressed. New York: Continuum; 2005.

17. Brasil. Ministério da Saúde. II Caderno de educação popular em saúde. Brasília: Ministério da 
Saúde; 2014 [acesso 2018 ago 16]. Disponível em: http://bvsms.saude.gov.br/bvs/publicacoes/2_ caderno_educacao_popular_saude.pdf

18. World Health Organization. World Health Report: Primary health care: Now more than ever. Geneva: WHO; 2008 [cited 2018 Aug 16]. Available from: http://www.who.int/whr/2008/whr08_en.pdf

19. Candau VM, Scaviano SB, Marandino M. Oficinas pedagógicas de direitos humanos. 2a ed. Petrópolis: Vozes; 1996.

20. Afonso MLM. Oficinas em dinâmica de grupo: um método de intervenção psicossocial. São Paulo: Casa do Psicólogo; 2006.

21. Beisiegel CR. Educação Popular: um encontro com Paulo Freire. São Paulo: Loyola; 1987.

22. Rubio DM, Berg-Weger M, Tebb SS, Lee ES, Rauch S. Objectifying content validity: Conducting a content validity study in social work research. Soc Work Res. 2003;27:94-104.

23. Streiner DL, Norman GR. Health measurement scales: A practical guide to their development and use. New York: Oxford University Press; 2014.

24. DeVellis RF. Guidelines in scale development. In: DeVellis RF. Scale development: Theory and applications. 4th ed. Thousand Oaks: Sage; 2017. p.73-114.
25. Brasil. Ministério da Saúde. Política nacional de alimentação e nutrição. Brasília: Ministério da Saúde; 2013 [acesso 2018 ago 16]. Disponível em: http://bvsms.saude.gov.br/bvs/publicacoes/ politica_nacional_alimentacao_nutricao.pdf

26. Pasquali L. Psicometria: teoria dos testes na psicologia e na educação. 5a ed. Petropolis: Vozes, 2003.

27. Aseer PAL, Maiya GA, Kumar MM, Vijayaraghavan PV. Content validation of total knee replacement rehabilitation protocol in indian population. J Clin Diagn Res. 2017;11:YC05-9. http://dx.doi. org/10.7860/JCDR/2017/27528.10137

28. Torres HC, Chaves FF, Silva DD, Bosco AA, Gabriel $\mathrm{BD}$, Reis IA, et al. Translation, adaptation and validation the contents of the Diabetes Medical Management Plan for the Brazilian context. Rev Lat-Am Enfermagem. 2016;24:e2740. http://dx.doi. org/10.1590/1518-8345.1138.2740

29. Brasil. Ministério do Desenvolvimento Social e Combate à Fome. Marco de referência de educação alimentar e nutricional para as políticas públicas. Brasília: MDS; 2012 [acesso 2018 ago 16]. Disponível em: https://www.ideiasnamesa.unb.br/ files/marco_EAN_visualizacao.pdf

Received: September 12, 2018

Final version: December 11, 2018 Approved: December 18, 2018 